Volume 9. Nomor 2. Januari 2014
Pandecta
http:/journal.unnes.ac.id/nju/index.php/pandecta

\title{
Peran Lembaga Amil Zakat Nasional Dalam Penghimpunan Dana Zakat, Infaq, dan Shodaqoh
}

\author{
Arif Kusmanto $\bowtie$
}

Juru sita Mahkamah Agung di Kabupaten Perigi, Sulawesi Tenggara, Indonesia

\section{Info Artikel}

Sejarah Artikel:

Diterima Oktober 2014

Disetujui November 2014

Dipublikasikan Desember 2014

Keywords:

Institute for National Zakat; Fund Raising;

Zakat Infaq Shodaqoh (ZIS)

\begin{abstract}
Abstrak
Tingkat kemiskinan masyarakat kota Semarang pada tahun 2009 sebanyak 73.000 jiwa dan tahun 2010 naik menjadi 80.000 jiwa (BPS Jateng 2011), karena suatu standar tingkat hidup yang rendah (Parsudi Suparlan), sehingga masyarakat Kota Semarang berpotensi untuk melaksanakan kewajiban zakat dalam usaha pengentasan kemiskinan. Namun potensi ini belum digali optimal. Penelitian ini mengkaji: Pertama, pola penghimpunan dana ZIS; Kedua, Faktor yang mempengaruhi penghimpunan dana ZIS; Ketiga, peran Laznas dalam penghimpunan dana ZIS. Jenis penelitian yang di gunakan adalah deskriptif kualitatif dengan pendekatan yuridis sosiologis, yang dianalisis menggunakan analisis data kualitatif. Hasil penelitian ini menunjukkan bahwa Pola penghimpunan dana ZIS yang cukup baik oleh DPUDT, PKPU, dan Rumah Zakat Semarang. Dengan layanan pembayaran melalui kantor, jemput zakat, atau layanan bank. Faktor pendukung penghimpunan dana ZIS antara lain faktor intern: lokasi yang strategis, SDM yang mumpuni, program pendayagunaan yang bagus, legalitas lembaga, kemampuan menyalurkan program, managemen baik, dan figuritas tokoh dan faktor ekstern: dukungan masyarakat, serta dukungan pemerintah. Sedangkan faktor penghambat antara lain faktor intern: keterbatasan SDM pengelola yang memiliki kompetensi, sistem yang belum berjalan optimal, tidak adanya kerjasama antar Laz dalam penghimpunan, melekatnya figur tokoh; faktor ekstern: budaya masyarakat yang belum membayar zakat melalui Laz, serta kebijakan pemerintah yang belum dapat dilaksanakan. DPU-DT, PKPU, dan Rumah Zakat Semarang sampai sekarang sudah berperan secara optimal sesuai UU dalam penghimpunan dana ZIS, terbukti dengan meningkatnya dana ZIS yang terhimpun serta muzakki.
\end{abstract}

\begin{abstract}
The poverty in Semarang City in 2009 as many as 73,000 inhabitants and in 2010 rose to 80,000 (Central Java BPS 2011), due to a low standard of living, so that the people of Semarang has the potential to carry out the obligation of zakat in poverty alleviation efforts. However, this potential has not been explored optimally. This study examines: First, the pattern of ZIS fund raising; Second, factors affecting the ZIS fund raising; Third, LAZNAS role in fund raising ZIS. This type of research used descriptive qualitative sociological juridical approach, which analyzed using qualitative data analysis. The results of this study indicate that the pattern of accumulation ZIS pretty good by DPU-DT, PKPU, and Zakat House Semarang. With payment services through the office, pick zakat, or bank services. Factors supporting fund raising ZIS include internal factors: strategic location, qualified human resources, good utilization program, the legality of the agency, the ability to deliver the program, good management, and figures and external factors: community support, as well as government support. While inhibiting factors include internal factors: lack of human resources managers who have the competence, the system is not running optimally, the absence of cooperation between Lazis in the collection, attachment figure figures; external factors: culture that has not paid zakat through Lazis, as well as government policies can not be implemented. DPU-DT, PKPU, and Zakat House Semarang until now has been instrumental optimally according to the Act in ZIS fund raising, as evidenced by the increase in the funds collected and muzakki ZIS.
\end{abstract}




\section{Pendahuluan}

Zakat dapat dimanfaatkan bagi kesejahteraan masyarakat terutama untuk mengentaskan masyarakat dari kemiskinan dan menghilangkan kesenjangan sosial, karena kemiskinan adalah Suatu standar tingkat hidup yang rendah, yaitu adanya suatu tingkat kekurangan materi pada sejumlah atau segolongan orang dibandingkan dengan standar kehidupan yang umum berlaku dalam masyarakat yang bersangkutan. (Suparlan, 1984). Masyarakat Kota Semarang pada dasarnya memiliki potensi yang besar untuk melaksanakan kewajiban zakat, dengan potensi zakatnya sekitar Rp. 369.020.400.000. (tiga ratus enam puluh sembilan miliar dua puluh juta empat ratus ribu rupiah). (Majalah Riptek, 2012) Masyarakat Kota Semarang banyak yang memiliki profesi dengan berpenghasilan tinggi, diantanya sebagai advokat, pegawai negeri sipil, dokter, pengusaha dan lain sebagainya. Akan tetapi banyak dari mereka yang telah memenuhi nishab masih rendah kesadaranya untuk berzakat. (Fatimah, 2011).

Dalam hal ini, lembaga amil zakat DPU-DT, PKPU, serta Rumah Zakat Semarang mempunyai peran yang penting untuk mengembalikan kepercayaan masyarakat kota Semarang dalam melaksanakan kewajibannya sebagai umat Islam serta menyalurkan dana mereka melalui lembaga pengelola zakat yang amanah, transparan dan akuntabel.

Melihat realitas tersebut, sebagai bagian dari anggota masyarakat, tentu kita tidak boleh hanya mengutuk keadaan, menyalahkan pemerintah. Akan tetapi harus ada usaha dari kelompok atau anggota masyarakat yang peduli dengan kondisi masyarakat Indonesia saat ini. Bukan berarti kita berpangku tangan melihat kondisi yang ada. Akan tetapi bagaimana mengoptimalkan potensi yang ada guna membantu pemerintah mengurangi jumlah penduduk miskin. Salah satu caranya adalah dengan mengoptimalkan peran Lembaga Amil Zakat Nasional (LAZNAS) dalam penghimpunan dana zakat, infaq, shodaqoh (ZIS).

Zakat dapat dimanfaatkanbagi kesejahteraan masyarakat terutama untuk men- gentaskan masyarakat darikemiskinan dan menghilangkan kesenjangan sosial, karena kemiskinan adalah suatu standar tingkat hidup yang rendah, yaitu adanya suatu tingkat kekurangan materi pada sejumlah atau segolongan orang dibandingkan dengan standar kehidupan yang umum berlaku dalam masyarakat yang bersangkutan. (Parsudi Suparlan, 1984:12)maka perlu adanyapengelolaan zakat secara professional dan bertanggung jawab yang dilakukanoleh masyarakat bersama pemerintah.Dalam masalah zakat juga harus mempertimbangkan kebutuhan riil penerima zakat, kemampuannya dalam memanfaatkan dana zakat untuk peningkatan kesejahteraan dan pembebasan diri dari kemiskinan, sehingga kedudukan sebagai mustahikbisa berubah menjadi muzakki (Zubaidi, 2007: 93).

Ibadah zakat meliputi sejumlah kegiatan yang berkaitan dengan pengelolaan zakat, yaitu mulai dari pengumpulan, pendistribusian, pengawasan, pengadministrasian dan pertanggungjawaban harta zakat. (Usman, 2002:163)Ibadah zakat akan terlaksana dengan baik, apabila zakat tersebutditangani dan dikelola oleh orang-orang yang professional dan dapatdipercaya. Dalam pengelolaan zakat, perlu diperhatikan bahwa para muzakkiharus mengetahui kemana harta zakat itu akan dibagikan dan dimanfaatkan.Lembaga zakat juga harus mempunyai dokumen dan data terperinci mengenaijumlah dana zakat yang diterima, orang yang membayarnya, kemana hartazakat itu digunakan. Sehingga, apabila sewaktu-waktu muzakki ingin tahu dataterperinci mengenai jumlah zakatnya, maka lembaga zakat tersebut bisamemberi jawaban. (Azizi,2004:144)

Selama ini dalam pelaksanaan zakat masih terjadi sikap kurang percaya terhadap lembaga pengelola zakat. Sikap kurang percaya tersebut akan dapat dikurangi, jika diciptakanorganisasi yang baik terutama sistem administrasinya, pengawasan yang ketat.Para amil zakat disyaratkan memenuhi beberapa kriteria, di antaranya dapatdipercaya, adil, mempunyai perhitungan yang benar, berakhlak baik,mempunyai pemahaman yang jelas tentang zakat, tidak dzalim dan tidakmenerima hadiah serta sogokan. (Al-Ba'ly, 2006:121) 
Lembaga amil zakat yang ada di kota semarang khususnya DPU-DT, PKPU, serta Rumah Zakat yang akan penulis teliti ini dibentuk oleh masyarakat untuk membantu dalam pelaksanaan pengumpulan, pendistribusian, dan pendayagunaan zakat (pasal 1 UU No.23 Tahun 2011), dengan tujuan agar dapat meningkatkan peran serta umat islam di Kota Semarang dalam rangka pembangunan manusia seutuhnya dengan optimalisasi pengumpulan dana zakat, infaq dan shodaqoh (ZIS).

Masyarakat Kota Semarang pada dasarnya memiliki potensi yang besar untuk melaksanakan kewajibannya berzakat.Banyak dari mereka memiliki profesi yang berpenghasilan tinggi, diantanyasebagai advokat, pegawai negeri sipil, dokter, pengusaha dan lain sebagainya. Akan tetapibanyak dari mereka yang telah memenuhi nishab masih rendah kesadaranya untuk berzakat. (Siti Fatimah, 2011:59)Dalam hal ini, lembaga amil zakat DPU-DT, PKPU, serta Rumah Zakat Semarang mempunyai peran yang penting untuk mengembalikan kepercayaan masyarakat kota Semarang dalam melaksanakan kewajibannya sebagai umat islam. Strategi-strategi dalam penghimpunan dana ZIS sangat diperlukan, salah satunya yaitu dengan sosialisasi tentang pentingnnya zakat kepada masyarakat secara terus-menerus dan berkesinambungan. Dengan sosialisasi yang baik dan optimal, diharapkan masyarakat akan semakin sadar membayar zakat melalui lembaga zakat yang kuat, amanah, dan terpercaya. Disamping itu, kerjasama atau kesepakatan mengenai pembagian wilayah kerja lembaga amil zakat nasional (LAZNAS) DPU-DT, PKPU, serta Rumah Zakat Semarang dalam melaksanakan tugasnya menghimpun dana zakat juga diperlukan agar supaya tidak ada tumpang tindih dalam menggarap potensi muzakki yang akan berzakat.

\section{Metode Penelitian}

Jenis penelitian adalah Metode Kualitatif dengan pendekatan Yuridis Sosiologis yang di gunakan untuk menggabungkan kaidah-kaidah hukum serta ketentuan peraturan perundang-undangan mengenai Peran
Lembaga Amil Zakat Nasional Dalam Penghimpunan Dana Zakat, Infaq. Pendekatan penelitian ini bersifat Yuridis Sosiologis, artinya pendekatan dengan melihat sesuatu kenyataan hukum didalam masyarakat (Ali, 2010). Penelitian tersebut melihat peran lembaga amil zakat dalam penghimpunan dana zakat, infaq, shodaqoh (ZIS), disamping melihat langsung ketentuan peraturan perundang-undangan yang mengatur pengelolaan zakat, juga melihat langsung yang terjadi dilapangan (lembaga amil zakat) atau field research. Peneliti dapat mendapatkan data yang akurat dan otentik yang dikarenakan penulis berhadapan langsung dengan informan, sehingga bisa langsung mewawancarai dan berdialog dengan informan. Sesungguhnya penulismendeskripsikan tentang obyek yang diteliti secara sistematis dan kemudian mengorganisir data-data yang diperoleh sesuai dengan fokus pembahasan penelitian. Sifat penelitian dalam penelitian ini adalah penelitian deskriptif. Penelitian deskriptif bertujuan menggambarkan secara tepat sifat-sifat suatu individu, keadaan, gejala atau kelompok tertentu, atau untuk menentukan penyebaran suatu gejala, atau untuk menentukan ada tidaknya hubungan antara suatu gejala dengan gejala lain dalam masyarakat. (Amiruddin, 2010)

\section{Hasil Penelitian dan Pembahasan}

\section{a. Pola Penghimpunan Dana Zakat, Infaq, Dan Shodaqoh (ZIS)}

Pola Penghimpunan masing-masing lembaga amil zakat DPU-DT, PKPU, serta Rumah Zakat Semarang mempunyai karakteristik sendiri-sendiri, namun pada prinsipnya sama, yaitu dengan berbagai macam strategi yang tentunya sangat membantu dalam keberhasilan penghimpunan dana ZIS. Hal ini sesuai dengan pendapat Eri Sudewo yang menyatakan bahwa inti kegiatan penghimpunan sesungguhnya terletak pada dua hal, yaitu galang dana dan layanan donatur. (Sudewo, 2004)

Dan sekarang yang perlu dilakukan oleh DPU-DT, PKPU, serta Rumah Zakat Semarang adalah dengan memaksimalkan penyuluhan (sosialisasi) tentang pentingnya 
kewajiban membayar zakat kepada masyarakat Semarang khususnya umat Islam, karena zakat adalah salah satu rukun Islam yang merupakan kewajiban agama yang dibebankan atas harta kekayaan seseorang menurut aturan tertentu. (Ali, 1988) dan juga meningkatkan pemahaman tentang hukum zakat dan memenuhi kebijakan-kebijakan yang dikeluarkan oleh pemerintah tentang pengelolaan zakat. Hal ini dikarenakan, selama ini pengetahuan masyarakat, pengusaha ataupun karyawan terhadap harta yang wajib dikeluarkan zakatnya masih terbatas, padahal kita melihat bahwa zaman semakin berkembang dan perlu bagi kita untuk mencermati lebih lanjut tentang harta-harta yang diwajibkan untuk dibayarkan zakatnya pada masa sekarang seperti yang sudah penulis sebutkan pada babbab terdahulu, yaitu zakat fitrah, dan zakat maal yang terdiri dari : (zakat ternak, zakat emas dan perak, zakat perniagaan, zakat hasil bumi, zakat hasil tambang dan barang temuan, zakat profesi, dan yang terakhir zakat saham dan obligasi).

Sedangkan untuk masyarakat perlulah kiranya DPU-DT, PKPU, serta Rumah Zakat Semarang mengoptimalkan media seperti khotbah Jum'at, majelis ta'lim, media cetak, media elektronik, media online dan brosurbrosur yang sifatnya praktis (agar mudah dipahami) untuk mengenalkan DPU-DT, PKPU, serta Rumah Zakat Semarang sehingga menarik minat masyarakat terhadap pentingnya memberikan sebagian hartanya untuk membayar zakat dan shodaqoh melalui lembaga amil zakat termasuk DPU-DT, PKPU, serta Rumah Zakat Semarang, karena selama ini hanya sedikit orang yang mengetahui pentingnya pengelolaan dana ZIS oleh lembaga yang amanah dan akuntabel.

Dalam penghimpunan dana ZIS, Laznas DPU-DT, PKPU, dan Rumah Zakat Semarang juga mempunyai berbagai macam layanan yang mempermudah para muzakki untuk membayar zakat, yaitu dengan cara datang langsung ke kantor, aksi jemput dan melalui layanan bank. Dari ketiga layanan pembayaran tersebut, menurut penuturan informan di ketiga lembaga amil zakat yang penulis teliti, layanan jemput zakat merupa- kan layanan yang paling efektif sampai saat ini. Petugas DPU-DT, PKPU, serta Rumah Zakat Semarang secara aktif mendatangi rumah para muzakki dan ini juga sesuai dengan firman Allah SWT dalam al-Qur'an surat at-Taubah ayat 103 yang mempunyai makna bahwa seorang amil atau petugas hendaknya mengambil zakat ke rumah para muzakki, tanpa harus menunggu muzakki datang.

Layanan jemput zakat ini merupakan layanan yang paling efektif dari pada layanan-layanan yang lain, alasanya karena:

a. kesibukan dari muzakki sehingga tidak dapat meluangkan waktunya untuk datang langsung ke kantor lembaga amil zakat sehingga membutuhkan penjemput zakat.

b. Kemantapan muzakki dalam membayarkan dana zakatnya kepada lembaga amil zakat melalui tim penjemput zakat dari pada melalui rekening, hal ini disebabkan tidak hanya karena kesibukan muzakki tetapi juga karena dihitungkan zakatnya, dan juga karena dido'akan ketika membayarkan zakatnya.

Dengan keaktifan petugas laznas DPUDT, PKPU, serta Rumah Zakat Semarang untuk mengambil zakat tanpa harus menunggu muzakki datang ke kantor pengelola zakat, mempunyai pengaruh yang besar terhadap jumlah dana ZIS yang dihimpun setiap tahunnya.

Berbagai kegiatan penghimpunan dana yang dilakukan laznas DPU-DT, PKPU, serta Rumah Zakat Semarang, diharapkan dana yang diterima laznas DPU-DT, PKPU, serta Rumah Zakat Semarang semakin meningkat setiap tahunnya. Maka untuk lebih meningkatkan potensi dana yang diterima dari masyarakat, laznas DPU-DT, PKPU, serta Rumah Zakat Semarang tidak hanya menghimpun dana zakat saja, tetapi juga dana lain seperti dana infaq/shadaqah. Hal ini sesuai dengan pasal 28 ayat 1 UU No. 23 Tahun 2011 yang intinya adalah selain menerima zakat, BAZNAS atau LAZ juga dapat menerima infak, sedekah, dan dana sosial keagamaan lainnya. 


\section{b. Faktor Yang Mempengaruhi Peng- himpunan Dana ZIS}

\section{Faktor Pendukung}

Ketiga lembaga amil zakat sebagian besar faktor pendukung penghimpunan dana ZISnya mempunyai persamaan. Namun dari beberapa faktor pendukung yang sama tersebut, ada juga faktor pendukung yang tidak sama dan tidak terdapat di lembaga amil zakat lain yaitu :

a. Pada laznas DPU-DT Semarang mempunyai faktor pendukung dari figuritas seorang tokoh kharismatik yang sudah di kenal oleh masyarakat luas yaitu K.H Abdullah Gymnastiar.

b. Pada PKPU Semarang mempunyai beberapa kantor cabang pembantu (KCP) di beberapa kota besar di Jawa Tengah yaitu KCP Purwokerto, Tegal, Kudus, Boyolali, dan Karanganyar. KCP seperti ini di LAZ-LAZ lain yang penulis teliti tidak mempunyai kantor cabang pembantu.

Dari berbagai faktor pendukung yang penulis sebutkan diatas, pastinya mempunyai pengaruh yang besar pada perolehan dana zakat dimana muzakki semakin mempercayakan dana zakatnya ke lembaga amil zakat, yang pada akhirnya tujuan zakat akan dapat terpenuhi. tujuan zakat ini telah dikemukakan oleh Moh. Daud Ali (1988:40) bahwa tujuan zakat tersebut: a) Mengangkat derajat fakir miskin dan membantunya ke luar dari kesulitan hidup serta penderitaan; b) Membantu pemecahan permasalahan yang dihadapi oleh para gharimin, ibnussabil, dan mustahiq lainnya; c) Menjalin tali persaudaraan sesama umat islam dan manusia pada umumnya; d) Menghilangkan sifat kikir pemilik harta; e) Membersihkan sifat dengki dan iri (kecemburuan sosial) dari hati orang-orang miskin; f) Menjembatani jurang pemisah antara yang kaya dengan yang miskin dalam suatu masyarakat; g) Mengembangkan rasa tanggung jawab sosial pada diri seseorang, terutama pada mereka yang mempunyai harta; h) Mendidik manusia untuk berdisiplin menunaikan kewajiban dan menyerahkan hak orang lain yang ada padanya; serta i)
Sarana pemerataan pendapatan (rezeki) untuk mencapai keadilan sosial. Setelah tujuan zakat dapat terpenuhi, hikmah dan manfaat zakat akan dapat dirasakan tidak hanya bagi pelakunya saja melainkan juga bagi umat Islam secara keseluruhan. (Majalah PKPU edisi 2 September-Oktober 2012)

Selain faktor-faktor diatas, faktor yang seharusnya juga mendukung keberhasilan lembaga amil zakat adalah adanya peran tokoh masyarakat. Peran tokoh masyarakat berperan penting dalam pemahaman terhadap masyarakat mengenai pentingnya menunaikan zakat dengan melalui lembaga amil zakat yang amanah dan terpercaya. Hal ini sesuai dengan pasal 35 ayat 2 butir a UU No.23 Tahun 2011 mengenai peran serta masyarakat dalam rangka pembinaan dengan meningkatkan kesadaran masyarakat untuk menunaikan zakat melalui BAZNAS dan LAZ.

\section{Faktor Penghambat}

Faktor-faktor yang menghambat teroptimalkannya penghimpunan dana ZIS baik dari sisi internal maupun dari sisi eksternal lembaga amil zakat, semuanya itu seharusnya dapat diatasi dengan baik sehingga dapat dijadikan evaluasi bagi lembaga amil zakat tersebut.

Mengatasi faktor-faktor yang menghambat kesuksesan penghimpunan dana ZIS pada lembaga amil zakat yaitu antara lain :

1. Pelatihan pengelolaan zakat harus di intensifkan, agar supaya SDM yang belum berpengalaman dibidangnya dapat segera mungkin beradaptasi dengan pekerjaannya.

2. Keterbatasan SDM yang mengakibatkan keluhan (komplain) dari muzakki/ donatur mengenai ketidakpuasan kinerja lembaga amil zakat harus disikapi dengan melakukan perbaikan diintern lembaga amil zakat tersebut, seperti : penambahan SDM, serta meingkatkan kinerja para pegawai.

3. Disatu sisi masyarakat semakin hari semakin sadar untuk berzakat, tetapi disisi yang lain masih banyak masyarakat yang belum sadar akan kewajibannya untuk berzakat. Di samping itu, 
budaya masyarakat masih belum memberikan kepercayaannya kepada lembaga zakat dan lebih memilih untuk membagikan zakatnya secara langsung ke mustahik ataupun masyarakat juga masih berpandangan ustadz atau kyai yang berhak mengelola zakat (ulama' sentris) karena mereka dianggap lebih berkompeten. Menyikapi hal ini, untuk memberikan edukasi kepada masyarakat mengenai kewajiban berzakat membutuhkan keterlibatan banyak pihak (tokoh masyarakat, pemuka agama, pemerintah, serta masyarakat pada umumnya).

4. Pembagian wilayah penghimpunan antar lembaga amil zakat guna memaksimalkan potensi zakat yang ada. Selama ini yang terjadi adalah saling tumpang tindih antar lembaga amil zakat dalam menggali potensi muzakki dikarenakan tidak ada pembagian wilayah penghimpunan. Tetapi dalam menyikapi wilayah kerja tersebut, pembagian itu tidak boleh menjebak organisasi terpuruk dalam dikotomi, melainkan harus dikemas sebagai simbiosis yang saling menguntungkan. (Sudewo, 2004)

5. Mengamalkan UU No.23 Tahun 2011 mengenai asas-asas dalam pengelolaan zakat, khususnya "Asas Terintegrasi" yang sangat penting untuk dilaksanakan lembaga amil zakat agar supaya pengelolaan zakat bisa dilaksanakan secara hierarkis dengan badan amil zakat (BAZ) yang dimiliki pemerintah, karena selama ini antar lembaga amil zakat ataupun dengan BAZ bentukan pemerintah sepertinya berjalan sendirisendiri, belum ada kerjasama dalam menggarap potensi zakat, sehingga harapannya pengelolaan zakat dalam artian pengumpulan, pendistribusian serta pendayagunaan dana zakat dapat dioptimalkan dengan melakukan kerjasama/kordinasi antar lembaga amil zakat serta dengan BAZ.

6. Tidak menggunakan kepopuleran figuritas seseorang atau nama-nama besar karena hal tersebut dapat berdampak buruk pada perolehan dana zakat apabila citra dari figur tersebut sudah mulai menurun di mata masyarakat. Oleh karena itu, yang seharusnya dilakukan oleh lembaga amil zakat adalah mengedepankan pengelolaan dana ZIS yang baik, amanah dan terpercaya tanpa melihat figur dibalik lembaga amil zakat tersebut serta dapat mendayagunakan dana tersebut tepat sasaran.

\section{c. Peran Lembaga Amil Zakat Nasional DPU-DT, PKPU, Dan Rumah Zakat Semarang Dalam Penghimpunan Dana ZIS}

Lembaga amil zakat DPU-DT, PKPU, dan Rumah Zakat Semarang mempunyai peran penting dalam menggarap potensi zakat yang sangat besar di kota Semarang dengan menggunakan berbagai macam strategi penghimpunan guna menarik perhatian para muzakki untuk berzakat di lembaga amil zakat tersebut, akan tetapi dengan melihat kenyataan di masyarakat, masih banyaknya masyarakat yang memenuhi nishab rendah kesadarannya untuk berzakat. (Fatimah, 2011)

Penghimpunan dana ZIS yang dilakukan oleh Laznas DPU-DT, PKPU, Serta Rumah Zakat Semarang selama tiga tahun ini, yaitu mulai tahun 2010 sampai tahun 2012 selalu mengalami kenaikan.

Yang pertama, perkembangan yang dialami oleh DPU-DT Semarang pada tahun 2010 berhasil menghimpun dana zakat sebesar Rp. 977.142.374 (sembilan ratus tujuh puluh tujuh juta seratus empat puluh dua ribu tiga ratus tujuh puluh empat rupiah), selanjutnya pada tahun 2011 sedikit mengalami penurunan yaitu sebesar Rp. 948.565.811 (sembilan ratus empat puluh delapan juta lima ratus enam puluh lima ribu delapan ratus sebelas rupiah, tetapi yang terakhir pada tahun 2012 potensi zakat dapat tergali lebih baik lagi sehingga perolehan dana zakat mengalami peningkatan kembali yaitu sebesar Rp. 1.054.183.840 (satu miliar lima puluh empat juta seratus delapan puluh tiga ribu delapan ratus empat puluh rupiah. Secara keseluruhan dapat diketahui bah- 
wa dana zakat yang berhasil dihimpun oleh DPU-DT Semarang selama tiga tahun terakhir yaitu sebesar Rp.2.979.892.025 (dua miliar sembilan ratus tujuh puluh sembilan juta delapan ratus sembilan puluh dua ribu dua puluh lima rupiah.

Kenaikan perolehan dana ZIS yang dihimpun oleh DPU-DT Semarang dipengaruhi oleh :

a. kesadaran masyarakat dalam beragama semakin meningkat terutama dalam kewajibannya untuk membayar zakat serta kepedulian masyarakat untuk menyisihkan sebagian hartanya yang akan diberikan kepada orang yang membutuhkan semakin meningkat.

b. Kepercayaan masyarakat terhadap lembaga pengelola zakat untuk mengelola dan mendayagunakan dana zakatnya semakin meningkat.

c. DPU-DT Semarang dalam pengelolaan dana ZIS yang semakin membaik dengan berbagai layanan dan programprogramnya.

d. Figuritas AA Gym yang melekat pada DPU-DT Semarang yang notabene pendiri dari DPU-DT

Yang kedua, perkembangan yang dialami oleh PKPU Semarang pada tahun 2010 berhasil menghimpun dana ZIS sebesar Rp. 4.862.584.497 (empat miliar delapan ratus enam puluh dua juta lima ratus delapan puluh empat ribu empat ratus sembilan puluh tujuh rupiah), kemudian pada tahun 2011 perolehan dana ZIS meningkat menjadi sebesar Rp. 6.015.580.043 (enam miliar lima belas juta lima ratus delapan puluh juta empat puluh tiga rupiah), dan pada tahun 2012 penghimpunan dana ZIS menembus angka Rp. 7.270.977.080 (tujuh miliar dua ratus tujuh puluh juta sembilan ratus tujuh puluh tujuh delapan puluh rupiah). Secara keseluruhan dari tahun 2010 sampai tahun 2012 dapat diketahui bahwa dana ZIS yang berhasil dihimpun oleh PKPU Semarang selama tiga tahun yaitu sebesar Rp. 18.149.141.620 (delapan belas miliar seratus empat puluh sembilan juta seratus empat puluh satu ribu enam ratus dua puluh rupiah).

Perolehan penghimpunan dana ZIS yang besar PKPU Semarang ini dipengaruhi oleh :

a. kesadaran masyarakat dalam beragama semakin meningkat terutama dalam kewajibannya untuk membayar zakat, serta kepedulian masyarakat untuk menyisihkan sebagian hartanya yang akan diberikan kepada orang yang membutuhkan semakin meningkat.

b. Kepercayaan masyarakat terhadap lembaga pengelola zakat untuk mengelola dan mendayagunakan dana zakatnya semakin meningkat.

c. PKPU Semarang dalam pengelolaan dana ZIS yang semakin membaik dengan berbagai layanan dan programprogramnya.

d. Unit-unit cabang pembantu PKPU Semarang yang berada di berbagai daerah di Jawa Tengah (Purwokerto, Tegal, Kudus, Boyolali, dan Karanganyar) yang bekerja dengan baik, sehingga dana yang terkumpul dapat terbilang cukup besar.

Yang ketiga, penghimpunan dana ZIS yang dilakukan oleh Rumah Zakat Semarang selama tiga tahun yaitu mulai tahun 2010 sampai tahun 2012 selalu mengalami kenaikan. Awalnya, pada tahun 2010 dana ZIS yang berhasil dihimpun yaitu sebesar Rp. 1.729.960.850 (satu miliar tujuh ratus dua puluh sembilan juta sembilan ratus enam puluh ribu delapan ratus lima puluh rupiah). selanjutnya pada tahun 2011 mengalami kenaikan menjadi Rp. 2.377.414.800 (dua miliar tiga ratus tujuh puluh tujuh juta empat ratus empat belas ribu delapan ratus rupiah. dan pada tahun 2012 kembali mengalami kenaikan menjadi Rp. 2.687.250.525 (dua miliar enam ratus delapan puluh tujuh juta dua ratus lima puluh ribu lima ratus dua puluh lima rupiah). Secara keseluruhan dapat diketahui bahwa dana ZIS yang berhasil dihimpun oleh Rumah Zakat Semarang selama tiga tahun yaitu sebesar Rp. 6.794.626.175 (enam miliar tujuh ratus sembilan puluh empat juta enam ratus dua puluh enam ribu seratus tujuh puluh lima).

Kenaikan perolehan penghimpunan dana ZIS pada Rumah Zakat ini dipengaruhi 
oleh :

a. kesadaran masyarakat dalam beragama semakin meningkat terutama dalam kewajibannya untuk membayar zakat, serta kepedulian masyarakat untuk menyisihkan sebagian hartanya yang akan diberikan kepada orang yang membutuhkan semakin meningkat.

b. Kepercayaan masyarakat terhadap lembaga pengelola zakat untuk mengelola dan mendayagunakan dana zakatnya semakin meningkat.

c. Pengelolaan dana ZIS dilakukan dengan manajemen yang baik, didukung dengan teknologi modern sehingga mempermudah dan menarik para muzakki untuk berdonasi di Rumah Zakat Semarang.

Alhasil, disini peran LAZNAS yang penulis teliti dalam menghimpun dana ZIS sudah cukup baik, dengan diketahui terus meningkatnya kesadaran masyarakat kota Semarang dalam melaksanakan kewajibannya berzakat yang berpengaruh pada peningkatan perolehan dana ZIS, akan tetapi dengan melihat begitu besarnya potensi zakat yang ada sepertinya peningkatan tersebut masih jauh dari kata ideal, karena sampai saat ini dana zakat belum bisa terhimpun dengan baik dikarenakan mereka membayarkan zakatnya di beberapa lembaga amil zakat, sehingga muzakki tidak bisa terkordinir dengan baik, indikator keberhasilan penghimpunan dana ZIS suatu daerah tidak dapat diketahui, dan pada akhirnya dana yang diperoleh suatu lembaga amil zakat tersebut tidak bisa digali secara maksimal.

Selain itu, tidak maksimalnya perolehan dana ZIS juga dikarenakan selama ini masyarakat lebih memilih untuk berzakat dengan cara langsung membagikan ke mustahik ataupun melalui ustadz atau kyai yang dianggap berkompeten untuk menghimpun dana zakat (ulama' sentris), sehingga dana zakat yang tersalurkan tidak dapat terkelola dengan baik, dan dikhawatirkan menimbulkan penyelewengan dalam penyalurannya karena tidak adanya pengawasan.

Oleh karena itu, Pentingnya Pengelolaan zakat oleh lembaga pengelola zakat, apalagi yang memiliki kekuatan hukum formal, akan memiliki beberapa keuntungan, antara lain : Pertama : Untuk menjamin kepastian dan disiplin pembayar zakat. Kedua : untuk menjaga perasaan rendah diri para mustahik zakat apabila berhadapan langsung untuk menerima zakat dari para muzakki. Ketiga: Untuk mencapai efisien dan efektifitas, serta sasaran yang tepat dalam penggunaan harta zakat menurut skala prioritas yang ada pada suatu tempat. Keempat: Untuk memperlihatkan syiar Islam dalam semangat penyelenggaraan pemerintahan yang islami. Sebaliknya, jika zakat diserahkan langsung dari muzakki kepada mustahik, meskipun secara hukum syariah adalah sah, akan tetapi di samping akan terabaikannya hal-hal tersebut di atas, juga hikmah dan fungsi zakat, terutama yang berkaitan dengan kesejahteraan umat, akan sulit diwujudkan. (Hafidhudin, 2006)

Peran lembaga amil zakat dalam penghimpunan dana ZIS untuk mengoptimalkan perolehan dana ZIS harus ditingkatkan dengan menggunakan berbagai macam strategi yang dilakukan secara maksimal. Hal ini sesuai dengan pendapat Eri Sudewo (2004:189) yang menyatakan bahwa inti kegiatan penghimpunan sesungguhnya terletak pada dua hal, yaitu galang dana dan layanan donatur.

Selanjutnya dalam melaksanakan kegiatannya, Lembaga amil zakat yang penulis teliti sudah melaksanakan kewajibannya yaitu melakukan kegiatan sesuai dengan program kerja yang telah dibuat, menyusun laporan termasuk laporan keuangan, mempublikasikan laporan keuangan yang telah diaudit melalui media massa, serta menyerahkan laporan kepada pemerintah. (Mubarok, 2007)

Pemerintah dalam hal ini juga harus dapat mengambil tindakan tegas dengan kebijakan-kebijakan mengenai organisasi pengelola zakat yang tanpa ijin beroperasi dari pemerintah dengan dapat dikenai tindak pidana pelanggaran yang termaktub dalam pasal 41 UU No.23 Tahun 2011 yang berbunyi :

"setiap orang dilarang dengan sengaja bertindak selaku amil zakat melakukan pengumpulan, pendistribusian, atau pendayagunaan zakat tanpa izin pejabat yang berwenang dipidana dengan pidana kurungan 
paling lama 1 (satu) tahun dan/atau pidana denda paling banyak Rp50.000.000,00 (lima puluh juta rupiah)".

Disamping itu, perlu adanya kebijakan pemerintah yang mewajibkan masyarakat yang sudah mencapai nishobnya untuk membayar zakatnya dilembaga amil zakat yang terpercaya, karena zakat merupakan rukun Islam yang merupakan kewajiban agama yang dibebankan atas harta kekayaan seseorang menurut aturan tertentu. (Ali, 1988) Selain itu, dalam UU No.23 Tahun 2011 yang memuat asas-asas pengelolaan zakat, khususnya "Asas Terintegrasi" yang sangat penting untuk dilaksanakan lembaga amil zakat agar supaya pengelolaan zakat bisa dilaksanakan secara hierarkis dengan badan amil zakat (BAZ) yang dimiliki pemerintah karena selama ini antar lembaga amil zakat ataupun dengan BAZ bentukan pemerintah sepertinya berjalan sendiri-sendiri, belum ada kerjasama dalam menggarap potensi zakat yang ada, sehingga yang terjadi adalah kurang maksimalnya perolehan dana ZIS yang diperoleh dengan melihat begitu besarnya potensi zakat yang ada, dan harapannya pengelolaan zakat dalam artian pengumpulan, pendistribusian serta pendayagunaan dana zakat dapat dikemas sebagai simbiosis yang saling melengkapi satu dengan yang lainnya.

\section{Simpulan}

Pola penghimpunan dana ZIS pada LAZNAS DPU-DT, PKPU, serta Rumah Zakat Semarang yang cukup baik. Hal ini dapat dilihat dari berbagai macam strategi penghimpunan serta layanan pembayaran.

Faktor yang mendukung penghimpunan dana ZIS tersebut antara lain adalah: a) faktor intern: lokasi yang strategis, SDM yang mumpuni, program pendayagunaan yang bagus, legalitas lembaga, kemampuan menyalurkan program, managemen yang baik, dan figuritas tokoh; b) faktor ekstern: dukungan dari masyarakat, serta dukungan pemerintah. Sedangkan untuk faktor yang menghambat antara lain adalah: a) faktor intern: keterbatasan jumlah SDM pengelola yang memiliki kompetensi, sistem yang belum berjalan secara optimal, tidak adanya kerjasama antar lembaga amil zakat dalam penghimpunan, masih melekatnya figur tokoh; b) faktor ekstern: budaya masyarakat yang lebih memilih untuk membagikan langsung maupun lewat ustadz/kyai, serta kebijakan pemerintah yang belum bisa dilaksanakan.

Peran lembaga amil zakat nasional DPU-DT, PKPU, dan Rumah Zakat Semarang dalam penghimpunan dana ZIS yang sudah cukup baik, dapat dilihat dari laporan jumlah dana ZIS yang terhimpun tahun 2010, 2011, dan tahun 2012 meningkat. Hal ini diiringi dengan peningkatan jumlah muzakki yang melakukan pembayaran zakat di LAZ.

Bagi LAZ dibutuhkan evaluasi mengenai pola penghimpunannya sehingga dana yang dihimpun dapat optimal, diantaranya pelatihan terhadap SDM, sosialisasi yang maksimal mengenai pentingnya kewajiban membayar zakat baik dari lembaga amil zakat, tokoh masyarakat, tokoh agama maupun pemerintah, serta Pemetaan wilayah penghimpunan dana zakat antar lembaga amil zakat guna memaksimalkan potensi zakat yang ada, dengan harapan diantara lembaga amil zakat tidak saling tumpang tindih dalam menggarap potensi muzakki. Bagi Muzakki : harapanya dapat meningkatkan kesadaran akan kewajiban untuk menunaikan zakat. Bagi Mustahik : harapanya dapat mensukseskan program-program yang dikembangkan lembaga zakat yang diberikan kepada mustahik. Bagi Pemerintah : harapannya peraturan pelaksanaan UU No.23 Tahun 2011 segera ditetapkan oleh pemerintah agar supaya undang-undang ini dapat segera di laksanakan oleh semua pihak.

\section{Daftar Pustaka}

Ali, Z. 2010. Metode Penelitian Hukum. Jakarta: Sinar Grafika.

Amiruddin. 2010. Pengantar Metode Penelitian Hukum. Jakarta:Rajawali Pers

Daud Ali, M. 1988. Sistem Ekonomi Islam: Zakat dan Wakaf. Jakarta: UI-Press.

Fatimah, Siti. 2011. Skripsi: Peran BAZ Dalam Meningkatkan Jumlah Wajib Zakat (Studi Kasus di BAZ Kota Semarang).

Hafidhuddin, D. 2006. Jurnal: Zakat Sebagai Tiang Utama Ekonomi Syari'ah. 
Mubarok, J. 2011. Laporan Akhir Tim Pengkajian Hukum Tentang Pengelolaan Zakat Oleh Negara Bagi Kepentingan Masyarakat. Jakarta: BPHN PUSLITBANG

Sudewo, E. 2004. Manajemen Zakat. Jakarta: Spora Internusa Prima

Majalah PKPU Edisi 2, September-Oktober 2012

Majalah Riptek Vol.6 Tahun 2012

Undang-Undang No.23 Tahun 2011 tentang Pengelolaan Zakat 